\title{
About the Artists: The Jaki-Ed Collective
}

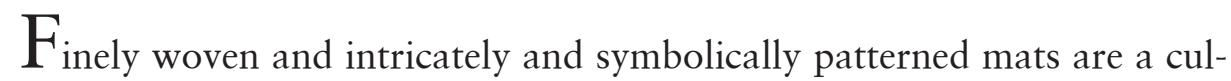
tural treasure of the Marshallese people. They are the expression of kōrō im an kōl (an attribute bestowed on all Marshallese women at birth) that grants women the opportunity to develop their unique talent and creativity. This form of creative expression is being revived through contemporary jaki-ed (finely woven mat).

Once used for clothing and for cultural, ceremonial, and domestic purposes, jaki-ed have been replaced by mass-produced clothing and furnishings. Marshallese master weaver Tibonieng Samuel recalled making her last clothing mat on Ujae during World War II when commercial ships, unable to enter the Pacific theater, could not deliver cotton fabric. Postwar economic and social factors have perpetuated the loss of traditional knowledge and cultural systems that characterized Marshallese society since the islands were first settled over two thousand years ago. As a consequence, knowledge of the traditional methods of weaving jaki-ed and the cultural meanings of the complex designs was rapidly disappearing.

Since 2006, the University of the South Pacific (USP)-Marshall Islands Campus and traditional leader Maria Kabua-Fowler, with the patronage of Iroij Michael Kabua as well as that of the Bernice Pauahi Bishop Museum in Honolulu, have been collaborating on projects and activities to ensure the revival and contemporization of jaki-ed. Basing designs on their own creative vision, weavers now use traditional patterns as inspiration for modern expressions. The UsP Jaki-Ed Program enables weavers to learn and share the cultural knowledge and customs associated with the fine mats while also building an exciting and sustainable creative industry. Although jaki-ed are no longer worn as clothing, the mats are now being collected as outstanding examples of cultural creativity.

DR IRENE TAAFAKI

Director, USP Marshall Islands Campus

The art featured in this issue can be viewed in full color in the online version of The Contemporary Pacific via Project MUSE. 

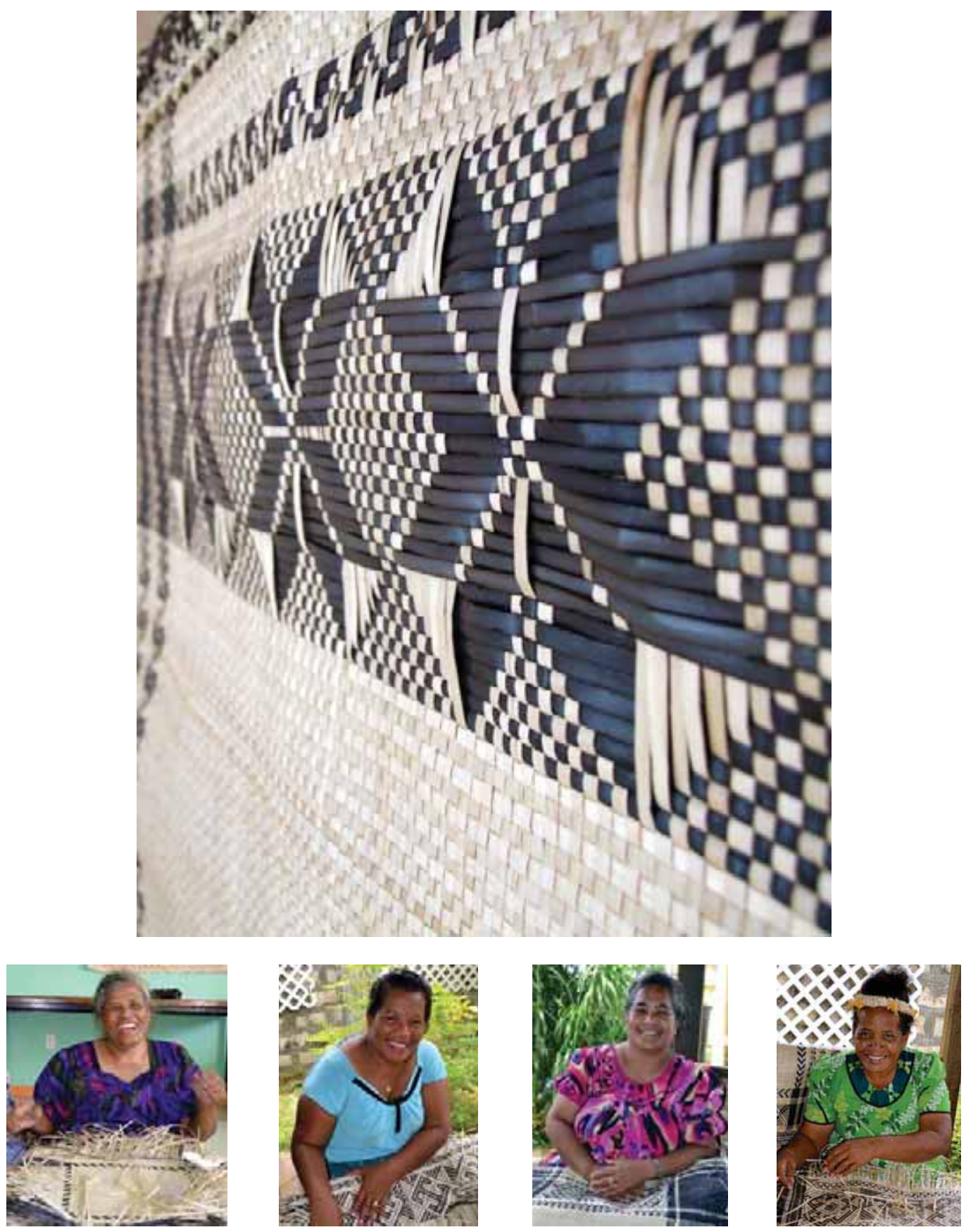

Above: Detail of a jaki-ed (fine mat) by Patsy Hermon. 2012.

Below, left to right: Terse Timothy, Susan Jieta, Patsy Hermon, and Ashken Binat are expert weavers involved with a program aimed at reviving the art of jaki-ed and training young weavers at the University of the South Pacific (USP) Marshall Islands. The initiative has resulted in revitalization of jaki-ed as well as contemporary interpretations of the customary techniques. Photos by K Earnshaw (Terse Timothy) and T Greenstone Alefaio. 


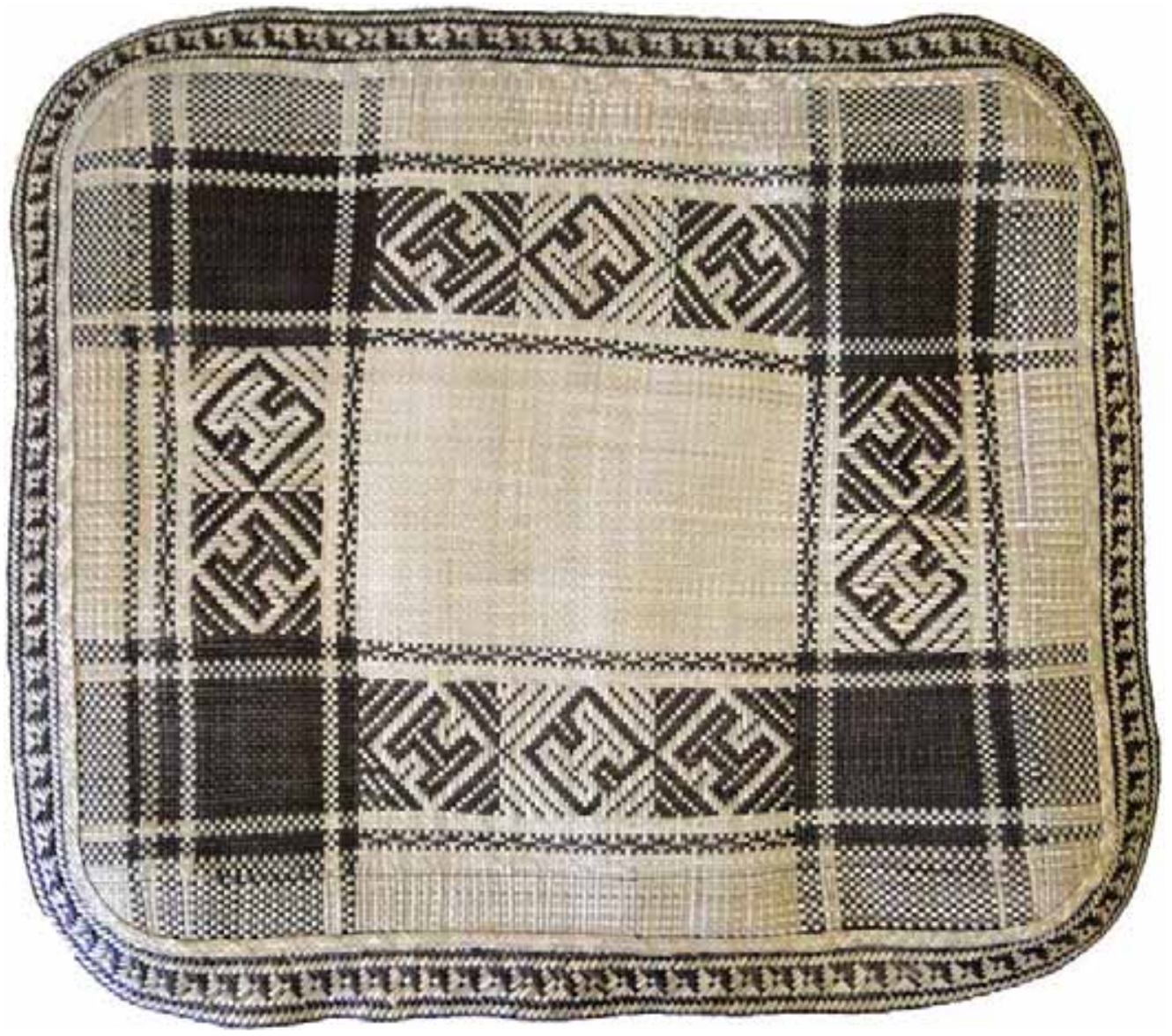

Jaki-ed (fine mat) by Terse Timothy. 20 Io.

Maā̄ (pandanus leaves), dye, string. $36 \times 30$ inches. Photo by K Earnshaw.

Terse Timothy is from Aelōn̄laplap Atoll and

Mājeej Island. She grew up watching her mother weave jaki-ed and continues to weave in this style because it connects her to her ancestors. 

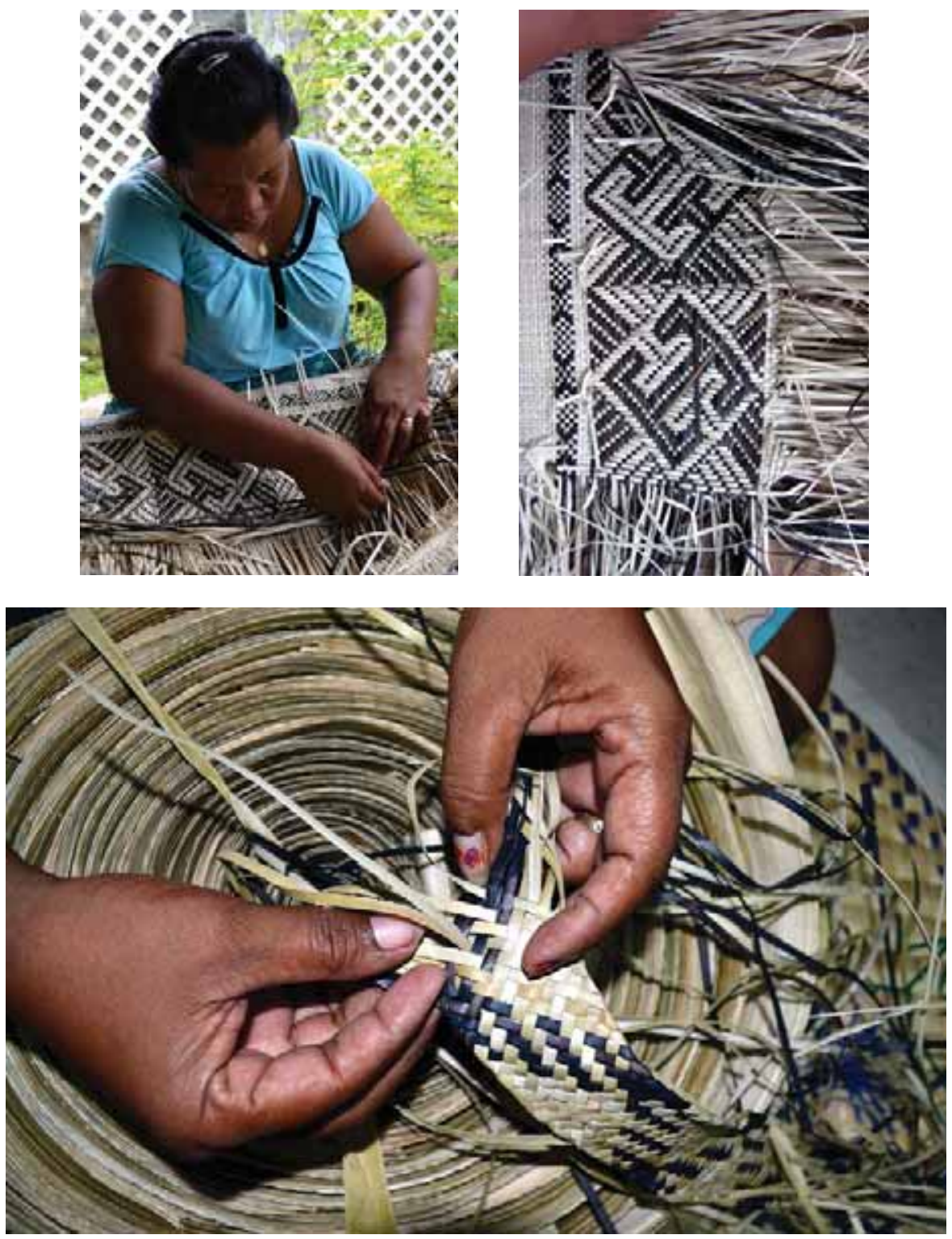

Above left, Susan Jieta weaves the kemejmej (design); above right, detail of the kemejmej; and below, she braids the in̄iñ of the jaki-ed (intertwined border of the fine mat). Photos by T Greenstone Alefaio.

Susan Jieta is from Mājeej Island. While in her twenties, Susan began weaving with a local women's group, and in 2007 she was introduced to the intricacies of jaki-ed through the UsP program. She weaves the kemejmej that traditionally referred to the complexities of land tenure and hierarchal relationships to tell stories of culture, environment, and natural and unnatural occurrences. The in̄iñ is braided to symbolize the interdependent relationship between one's father's and mother's lineages. 

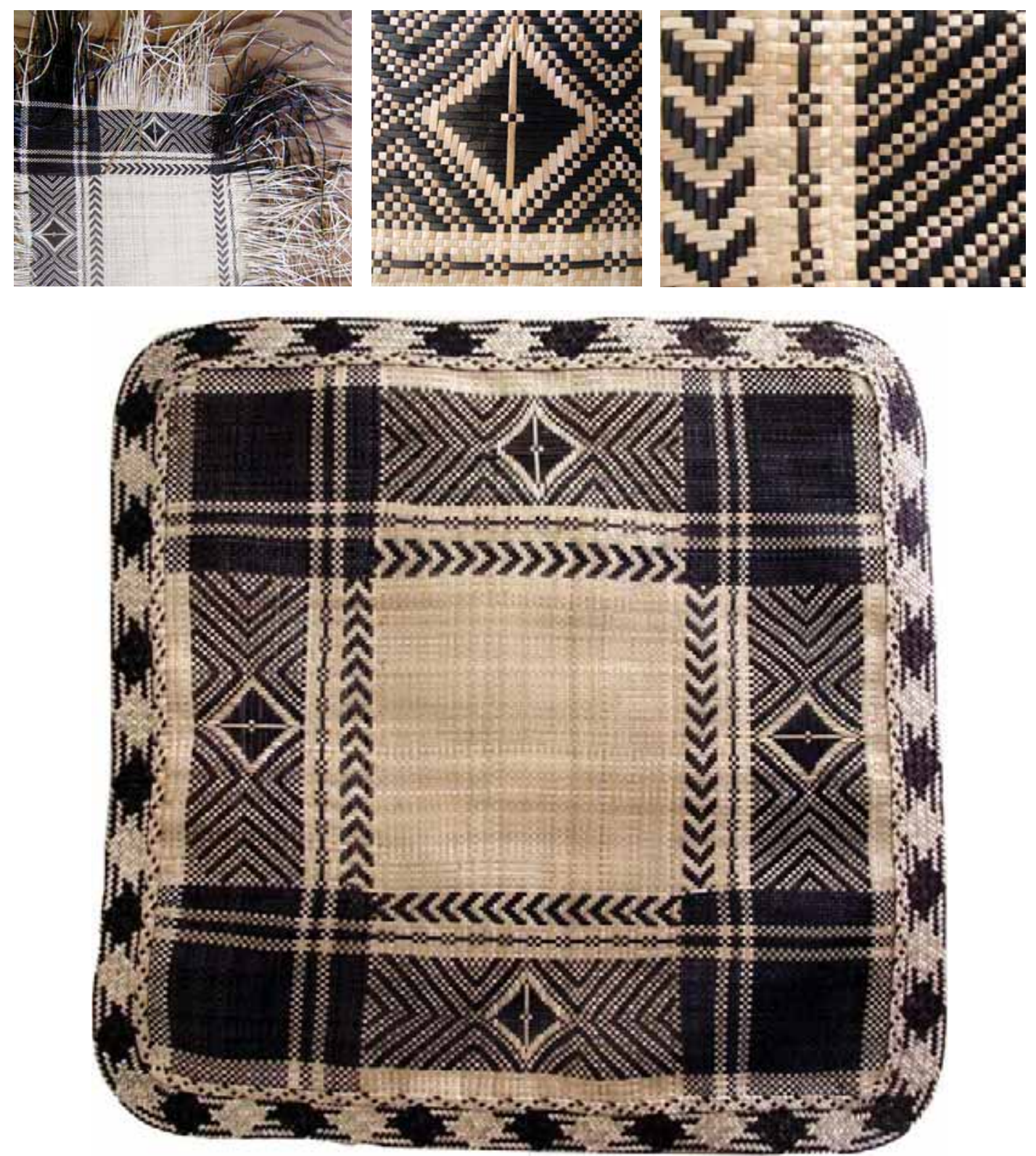

Jaki-ed (fine mat) by Susan Jieta. 2012.

Maañ (pandanus leaves), dye, string. $36 \times 36$ inches. Collection of Natalie Nimmer. Photos by K Higgins.

Susan Jieta endeavors to create elaborate designs in her jaki-ed. In this one Susan has combined the motif of "the star of the eye" (a cross in the center of a diamond) with the underbelly of a turtle (stylized rhombus repetition). This is one of the ways in which she pays tribute to the customs of her ancestors through contemporary jaki-ed. 


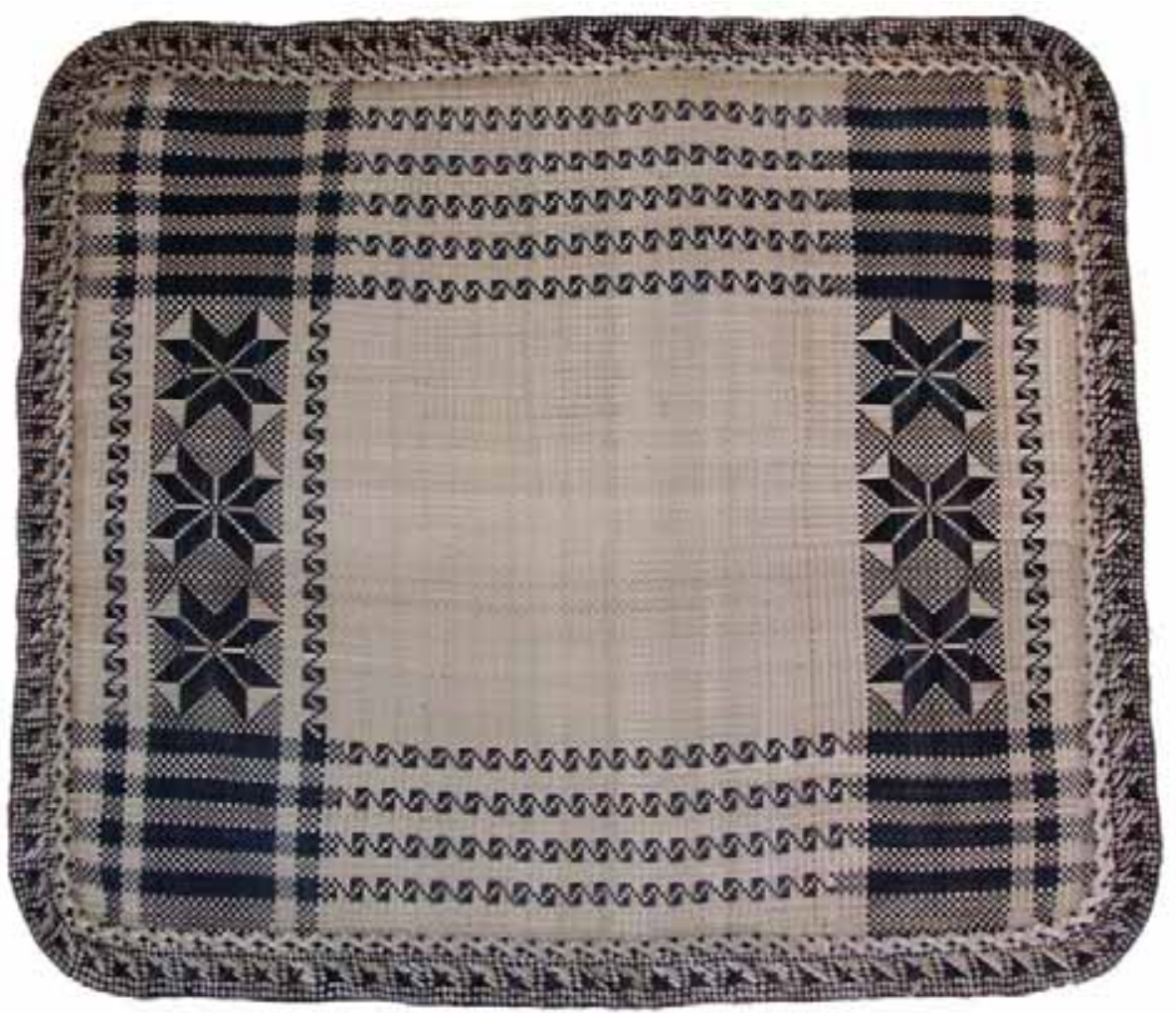

Jaki-ed (fine mat) by Patsy Hermon. $20 \mathrm{I} 2$.

Maañ (pandanus leaves), dye, string. 37 X 3 I inches. Collection of Rachel Miller. Photos by K Higgins. Patsy Hermon is from Namdik Atoll, where her mother also wove jaki-ed. Patsy wove her first fine mat at the age of ten and continues weaving to keep her culture alive for the future. 

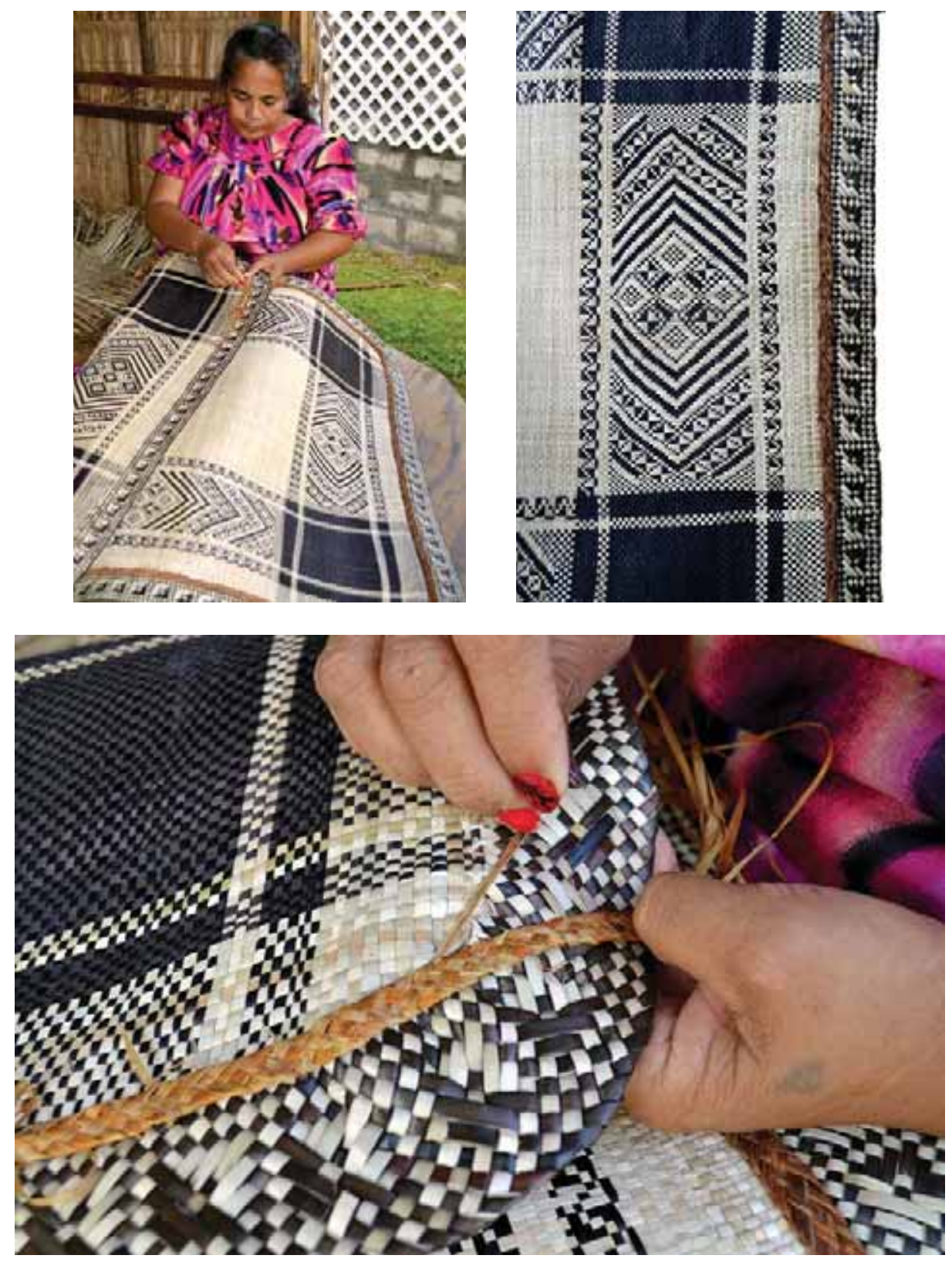

Jaki-ed (fine mat) by Patsy Hermon. 201 2.

Maañ (pandanus leaves), atat (stems of the beach burr plant), lo (bark of the hibiscus tree), dye, string. $48 \times 36$ inches. Photos by T Greenstone Alefaio. The bokwōj (literally, to embrace) overlay that covers the seams and attaches the jouj (heart) and inin̄ (border) of the mat is made from atat, which is harvested from outer islands. Bọkwōj symbolizes a parental embrace safeguarding the bonds of love, peace, and harmony among members of a jowi (clan). This traditional design element is an example of a technique that master weavers like Patsy Hermon are reviving and reintroducing. 

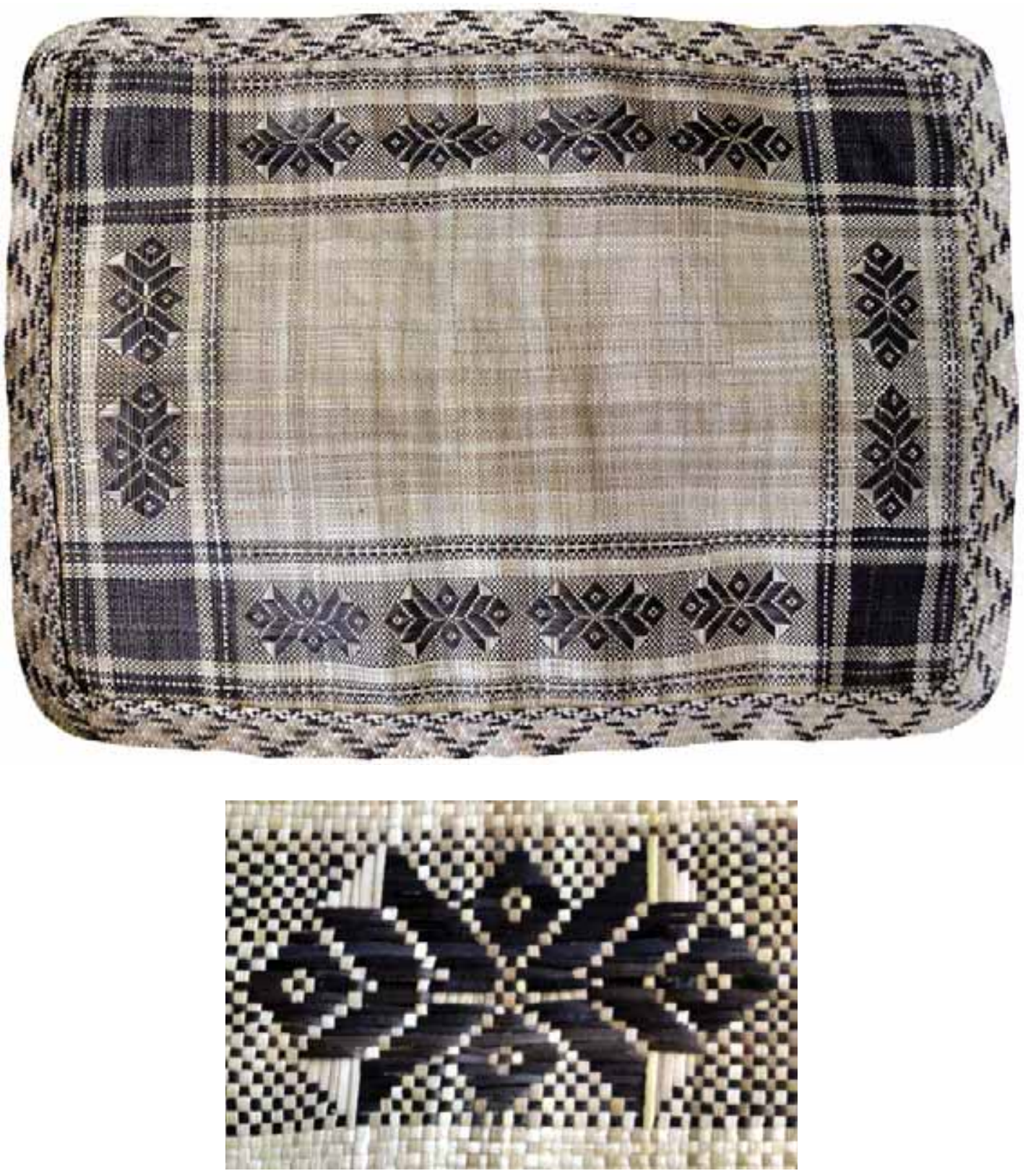

Jaki-ed (fine mat) by Ashken Binat. 20 IO.

Maañ (pandanus leaves), dye, string. I $8 \times 30$ inches.

Photos by T Greenstone Alefaio.

Ashken Binat is from Arno Atoll and Jebat Island. As a child, she watched her mother weave. Ashken made her first jaki-ed at the age of seventeen. One of Ashken's four daughters continues the family tradition of jaki-ed. The kemejmej (design) of this mat incorporates the pattern left in the sand by akkin om (small hermit crabs). 

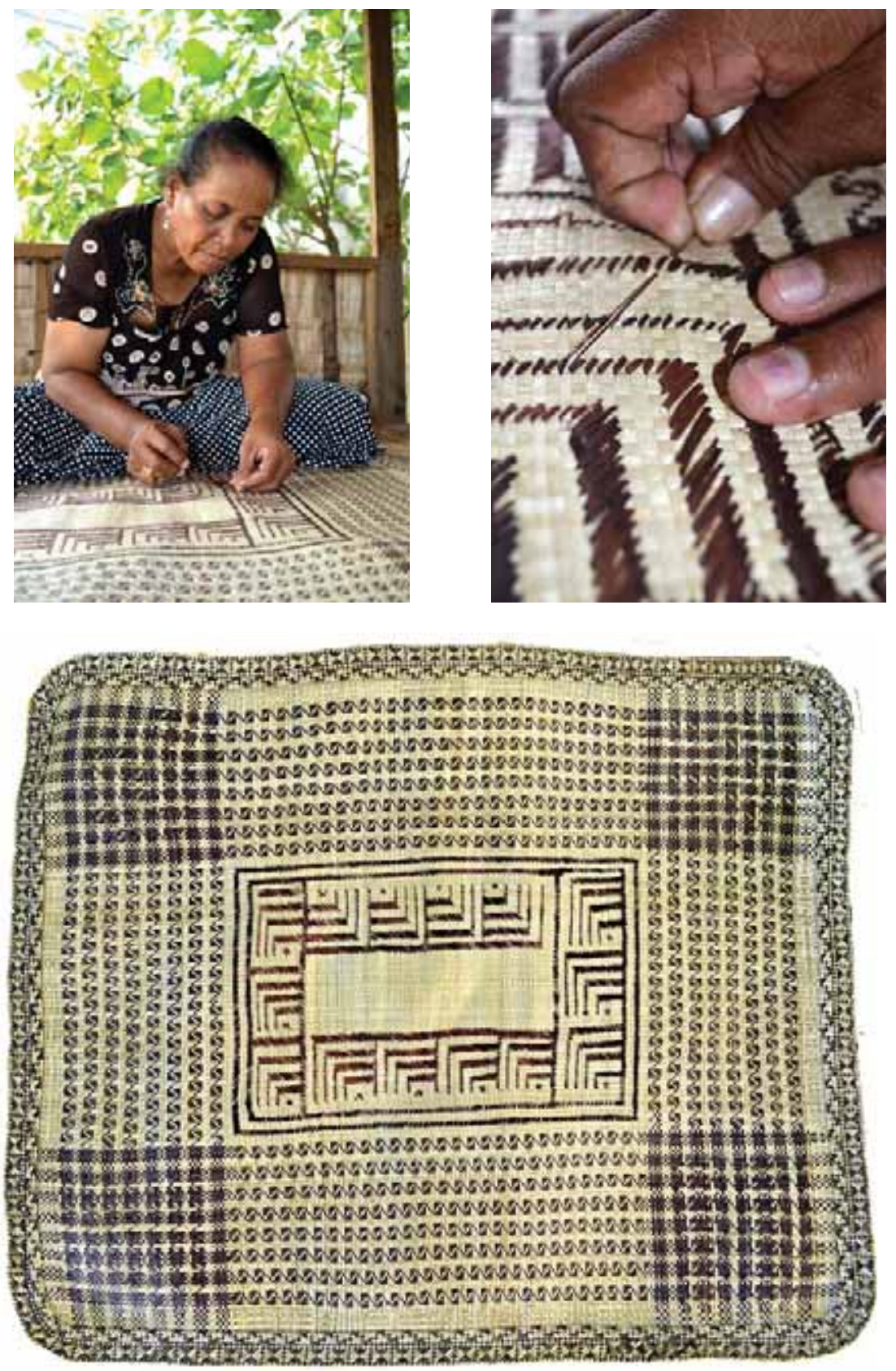

Jaki-ed (fine mat) by Ashken Binat. 20I 2.

Maañ (pandanus leaves), lo (bark of the hibiscus tree), dye, string. $48 \times 42$ inches. Photos by T Greenstone Alefaio.

Ashken Binet strives to create unique designs in her work. She uses a needle to add intricate and innovative patterns to the jouj (heart), while the zigzag in the kemejmej (design) includes the traditional motif that refers to the thousands of islets spread across the Marshall Islands' twenty-nine atolls. 